American University Washington College of Law Digital Commons @ American University Washington College of Law

4-6-2011

\title{
The Evolution of Operational Policies and
} Procedures at International Financial Institutions: Normative Significance and Enforcement Potential

Daniel Bradlow

Andria Naude Fourie

Follow this and additional works at: http://digitalcommons.wcl.american.edu/fac_works_papers Part of the Law Commons

\section{Recommended Citation}

Bradlow, Daniel David and Naude Fourie, Andria, The Evolution of Operational Policies and Procedures at International Financial Institutions: Normative Significance and Enforcement Potential (April 6, 2011).

This Article is brought to you for free and open access by the Works at Digital Commons @ American University Washington College of Law. It has been accepted for inclusion in Working Papers by an authorized administrator of Digital Commons @ American University Washington College of Law. For more information, please contact fbrown@wcl.american.edu. 


\section{International Law Association: Study Group: Responsibility of International Organisations}

\section{The Evolution of Operational Policies and Procedures at International Financial Institutions: Normative Significance and Enforcement Potential}

\section{Draft Report, April 2011}

\section{Daniel D. Bradlow and Andria Naudé Fourie*}

\section{Abstract}

The exact contours of international organisations' (IO) responsibility have not yet been clearly defined. While IOs - and international financial institutions (IFIs) in particular - have in the past avoided drawing those contours in more certain terms, this position is slowly changing: IFIs have been changing expectations about their standards of conduct, as reflected in their evolving operational policies and procedures $(\mathrm{OP} \& \mathrm{P})$. This report provides an overview of the content, formulation, adoption, amendment and enforcement of OP\&P at multilateral development banks (MDB) (a subset of IFIs). It highlights the impact of three developments that are strengthening the normative significance and enforcement potential of the OP\&P, namely: broadening stakeholder participation in OP\&P revision processes; 'hardening' or legalization of OP\&P through the compliance procedures of independent accountability mechanisms (IAM) - now widely established at MDBs; and the emerging enforcement potential of the IAMs.

\footnotetext{
* Daniel D. Bradlow is the SARCHI Professor of International Development Law and African Economic Relations, at the Faculty of Law of the University of Pretoria in South Africa; Professor of Law at American University Washington College of Law, and is the Chairperson of the Roster of Experts of the Independent Review Mechanism at the African Development Bank. The views expressed in this report are his own and should not be attributed to the Independent Review Mechanism. Andria Naudé Fourie is Assistant Professor of Public International Law, at the Erasmus School of Law in Rotterdam in The Netherlands. She defended her Ph.D in Public International Law (cum laude) on the World Bank Inspection Panel in October 2009.
} 


\section{Acronyms and Abbreviations}

African Development Bank AfDB

Asian Development Bank ADB

European Bank for Reconstruction and Development $\quad$ EBRD

Project Complaint Mechanism PCM

Independent Accountability Mechanism IAM

International Covenant on Civil and Political Rights ICCPR

Inter-American Development Bank IDB

International Bank for Reconstruction and Development IBRD

International Development Association IDA

International Finance Corporation $\quad$ IFC

Compliance Advisor / Ombudsman CAO

International Financial Institution IFI

International Organisation $\quad$ IO

Multilateral Development Bank MDB

Operational Policies and Procedures $\quad$ OP\&P

Project Affected People PAP

World Bank $\quad$ WB

Business Procedure BP

Independent Evaluation Group IEG

Quality Assurance Group QAG

Operational Policy OP

Department of Institutional Integrity INT

World Bank Inspection Panel WBIP

Eligibility Report IR

Investigation Report (Executive Summary) IR (ES)

Management Response (to ER) MR

Management Response to Investigation Report $\quad$ MR to IR 


\section{Introduction}

A key issue in the debate surrounding the responsibility of international organisations (IO) concerns the contours of these institutions' international legal obligations - or, what are IOs responsible for; to whom; and how might such obligations be enforced? ${ }^{1}$ A conventional response to these questions is that, while IOs do have international legal obligations, including obligations towards individuals, ${ }^{2}$ the sources and content of those obligations remain opaque. In addition, the mechanisms for enforcing these obligations, insofar as they exist at all, remain weak (Horta 2002). ${ }^{3}$ This argument is typically substantiated by the fact that IOs are not usually signatories to international conventions, and particularly not those regulating environmental and human rights obligations (Clark 2002; Darrow 2006). ${ }^{4}$

However, as we argue in this report, this position is slowly changing. This phenomenon can be seen most clearly and dramatically in the case of international financial institutions (IFIs) (Bradlow \& Hunter (eds.) 2010), which will be the primary focus of this report. Motivated by various external factors (such as pressure by international civil society and local governments, media scrutiny, and changing views of corporate responsibility for the adverse effects of actions), IFIs have been raising their own expectations about their standards of conduct (Danaher (ed. 1994); Shihata 2000; Alfredsson \& Ring (eds.) 2001; Clark et al. 2003; Head (2004); and Bradlow \& Hunter (eds.) 2010).

\footnotetext{
${ }^{1}$ See Scott 2000, at 38, raising the notion that the accountability issue has to be analysed from various perspectives; this approach also reflected in the ILA's 2004 report on the Accountability of International Organisations.

${ }^{2}$ See e.g., 2001 Chad Petroleum Development \& Pipeline Project, MR, at para. 16 (the Bank repeating the (then) standard WB position that the Bank's mandate only covered socio-economic rights obligations towards individuals, and not civil and political human rights. The Inspection Panel pointed out that 'human rights' (making no distinction between categories of rights) were 'implicitly embedded in various policies of the Bank' (2001 Chad Petroleum Development \& Pipeline Project, IP Chairperson Address, at 8).

${ }^{3}$ Also see section 3.2 below.

${ }^{4}$ Note that IOs are frequently signatories of treaties concerning financial or economic topics (e.g., development, trade, investment) - see e.g., Klabbers 2002, at 40-42; and Alvarez 2005 at 273-337.
} 
Both the source and the expression of these heightened expectations is the operational policies and procedures (OP\&P) of IFIs, which are internal documents that contain prescriptions ('rules', 'guidelines' and 'procedures') - addressed to both IFI staff and external parties, such as borrowers - concerning the manner in which the operations of the organisation ought to be performed. Hence, the OP\&P cover a wide range of functional areas, such as environmental and social safeguards, procedures to be followed when assessing, designing and implementing development projects, and technical details such as disbursing funds, preparing for missions etc. ${ }^{5}$ OP\&P could be - and increasingly are - compared to administrative rules and procedures found in domestic law, and as such is evolving into, what is called by some, 'global administrative law' (Kingsbury et al. 2005; Hunter in Bradlow \& Hunter 2010).

Moreover, as this report illustrates, the normative significance and enforcement potential of the OP\&P are being enhanced through regular internal policy revision processes and the evolving practice of 'Independent Accountability Mechanisms' (IAMs). IAMs, now present in some form at most IFIs, are internal bodies with varying (although significant) degrees of institutional independence that are tasked with investigating and/or resolving complaints from people who claim that they have been harmed or threatened with harm by the failure of the IFI to comply with its OP\&P (Shihata 2000; Bradlow 2005; Van Putten 2008). Some of them are also mandated to provide advice to the IFI on the further development of its OP\&P. ${ }^{6}$

In other words, the emphasis of the debate concerning the contours of the international legal obligations of IOs seems to have shifted over the past two decades or so from 'getting them to comply' with international standards, such as human rights standards (especially those contained in the ICCPR) in the abstract, to getting IOs to incorporate or 'mainstream' international human rights and environmental standards into their operations. ${ }^{7}$ In this sense, IOs - and the IFIs in particular - are

\footnotetext{
${ }^{5}$ For more detail, see section 2.1 below.

${ }^{6}$ These compliance procedures may be triggered internally (e.g., by the IO's Executive Board or President), by state parties (e.g., in case of a treaty body), or by other external stakeholders (e.g., NGOs or individuals). For a comparative perspective on various institutional aspects of the IAMs, see Bradlow \& Naudé Fourie, in Hale \& Held (eds.), forthcoming.

7 A sentiment consistently echoed in various initiatives surrounding the UN's Millennium Development Goals - see http://www.un.org/millenniumgoals/.
} 
truly becoming law-making bodies through the manner in which they draft, interpret and apply their OP\&P (Alvarez 2006).

\subsection{This report}

The report focuses on the OP\&P of a subset of IFIs, namely, the Multilateral Development Banks (MDBs), which specifically includes: the International Bank of Reconstruction and Development (IBRD) and International Development Association (IDA) - the 'World Bank' (WB); ${ }^{8}$ the International Finance Corporation (IFC) ${ }^{9}$ the Inter-American Development Bank (IBD); ${ }^{10}$ the Asian Development Bank (ADB); ${ }^{11}$ the European Bank for Reconstruction and Development (EBRD); ${ }^{12}$ and the African Development Bank (AfDB). ${ }^{13}$

The motivation behind this emphasis is twofold. First, OP\&P at the MDBs have reached a level of detail and scope yet to be reached by most other IOs. For example, the World Bank already had a policy on indigenous people - the WB's Operational Manual Statement 'Tribal People in Bank-Financed Projects - in 1982 (Kingsbury 1999, at 342; Hunter in Bradlow \& Hunter (eds.) 2010, at 202-204). Second, the MDBs all have existing IAMs that have undergone a fair degree of institutional development and have amassed a significant body of 'jurisprudence' over the past decade or so. ${ }^{14}$

8 See http://www.worldbank.org/, with emphasis on the WB's Inspection Panel (IP) (http://www.inspectionpanel.org).

9 See http://www.ifc.org/, with emphasis on the Compliance Advisor Ombudsman (CAO) (http://www.cao-ombudsman.org/).

10 http://www.iadb.org/en/about-us/about-the-inter-american-development-bank,5995.html, with emphasis on the Independent Consultation and Investigation Mechanism (MICI - as per the Spanish acronym) and its predecessor, the Independent Investigation Mechanism (http://www.iadb.org/en/mici/independent-consultation-and-investigation-mechanism-mici,1752.html). 11 http://www.adb.org/default.asp, with emphasis on the Accountability Mechanism (AM) (http://www.adb.org/Accountability-Mechanism/default.asp).

12 http://www.ebrd.com/pages/homepage.shtml, with emphasis on the Project Complaint Mechanism (PCM) and its predecessor, the Independent Recourse Mechanism (http://www.ebrd.com/russian/pages/about/principles/integrity/pcm.shtml).

13 http://www.afdb.org/en/, with emphasis on the Independent Review Mechanism (IRM) (http://www.afdb.org/en/about-us/structure/independent-review-mechanism/).

${ }^{14}$ See below, note 58 . 
The report will provide a general overview of the content of OP\&Ps, their formulation, adoption, amendment ('rule-making procedures') and their enforcement. It will highlight three developments that are arguably strengthening the normative significance and enforcement potential of the OP\&P, namely: the broadening stakeholder participation in OP\&P revision processes; the 'hardening' or legalization of OP\&P through IAM compliance procedures; and the emerging enforcement potential of the IAMs. The report will conclude with a few preliminary observations.

\section{Overview of operational policies and procedures at multi-lateral development banks}

This section provides an overview of the functional content covered by OP\&P at the MDBs (2.1), followed by a brief description of the procedures by which OP\&P are formulated, adopted and amended (2.2) as well as enforced (2.3). For a structured comparison between the MDBs, see Appendix 7.1 below.

\subsection{Content}

Over time, the OP\&P at MDBs have come to cover all functional areas flowing from the main objectives of these institutions, which can be summarized as the provision of lending products and related expertise - in line with the MDBs' development strategies - that support both development projects and programmes in their member states. ${ }^{15}$ Consequently, the OP\&P of MDBs typically govern the appraisal, design and implementation of development projects and programmes; as well as the anticipation, prevention and mitigation of various potential adverse effects that may flow from these activities.

\subsubsection{Classifying OP\&P}

MDBs employ combinations of different categorizations for their OP\&P, such as sector-specific (e.g., forestry and mining) vs. cross-sectoral policies (e.g., anticorruption and procurement policies) and country/region-specific policies (e.g.,

\footnotetext{
${ }^{15}$ For a historic overview of the development of OP\&Ps at the WB, see Shihata 2000, at 2-14; Kingsbury 1999, at 324-325; and Hunter in Bradlow \& Hunter 2010, at 202-209.
} 
regional and sub-regional cooperation). The most common classifications, however, are functional in nature. ${ }^{16}$ For example:

(1) 'safeguard' policies that aim to manage various social and environmental risks inherent in development projects, and to ensure sustainable development (e.g., policies on environmental impact assessments, indigenous people, involuntary resettlement);

(2) public information disclosure policies, clarifying which project-related information must be made available to different stakeholders (e.g., project affected people (PAP) or civil society), and at what stage of the project cycle;

(3) management and project supervision policies, which set out MDB obligations (often vis-à-vis the borrower) in the appraisal, design, and implementation of development projects;

(4) policies detailing the procedures concerning the MDB's independent accountability mechanism (IAM), as well as other internal and external accountability and development effectiveness measures (e.g., procurement policies, and policies ensuring institutional integrity, detecting fraud and corruption); ${ }^{17}$

(5) policies aiding staff in the development and application of its lending products (e.g., lending eligibility and terms);

(6) policies aimed at higher strategic levels in the MDB, such as regional, country and sector-specific strategy policies that aim to assist the MDB in its formulation of development strategies (e.g., country assistance management, poverty reduction).

Another useful classification increasingly being employed by MDBs concerns the differentiation between borrower and. MDB obligations. ${ }^{18}$ The blurred lines of

\footnotetext{
${ }^{16}$ Another classification might relate to the substantive vs. procedural elements in policies. While most OP\&P contain both substantive and procedural elements, some focus more on procedural issues (e.g., policies setting standards concerning stakeholder consultation and public disclosure of project-related information).

${ }^{17}$ Note that the IAMs' 'founding documents' detailing their operating procedures did not necessarily start out as part of the MDBs' set of OP\&P. For instance, the WBIP's founding Resolution and 1996 \& 1999 Board Clarifications on the Resolution were only later formally incorporated into the Bank's OP\&P structure as BP 17.55 (with Resolution and Board Clarifications Annexes to the BP).

${ }^{18}$ MDBs might also differentiate between policies aimed at public sector vs. private sector clients.
} 
responsibility between Banks and borrowers - essentially, where obligations of both are stipulated in the same OP\&P - has been a consistent contentious issue (Shihata 2000, at 13) in the history of OP\&P evolution. By adopting separate OP\&P (on similar functional areas) for the MDB and its borrowers (or 'clients') respectively, some of the banks have started to address this problem - especially with regards to their private sector clients. ${ }^{19}$

An intriguing development is the emergence of a tiered structure among the OP\&P that might even be suggestive of a legal hierarchy. ${ }^{20}$ Formal designations differ among the institutions but, roughly speaking, MDBs appear to organize their OP\&Ps into two levels or tiers. 'Policies', ${ }^{21}$ 'procedures', ${ }^{22}$ 'directives', ${ }^{23}$ or 'performance standards ${ }^{24}$ that establish norms with which MDB staff and borrowers are required to

${ }^{19}$ See e.g., the IFC's set of 'Performance Standards for Private Sector Clients' vis-à-vis its 'Policy on Advisor/Ombudsman (CAO)’ policy, which details only its own (MDB) obligations. Also see Daniel D. Bradlow and Megan S. Chapman, "Public Participation and the Private Sector: The Role of Multilateral Development Banks and the Evolving Legal Standards", Erasmus Law Review (forthcoming).

${ }^{20}$ See e.g., Klabbers 2002, at 224-226 on the significance of hierarchy among IO 'legislative instruments' or 'legal acts'.

${ }^{21}$ See e.g., WB definition: 'Operational Policies (OPs) are short, focused statements that follow from the Bank's Articles of Agreement, the general conditions, and policies approved by the Board. OPs establish the parameters for the conduct of operations; they also describe the circumstances under which exceptions to policy are admissible and spell out who authorizes exceptions.' (http://web.worldbank.org/WBSITE/EXTERNAL/PROJECTS/EXTPOLICIES/EXTOPMANUAL/0,_c ontentMDK:20249090 menuPK:64701643 pagePK:64141683 piPK:64141620 theSitePK:502184,00

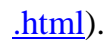

${ }^{22}$ See e.g., WB definition: 'Bank Procedures (BPs) explain how Bank staff carry out the policies set out in the OPs. They spell out the procedures and documentation required to ensure Bankwide consistency and quality.' (http://web.worldbank.org/WBSITE/EXTERNAL/PROJECTS/EXTPOLICIES/EXTOPMANUAL/0,,c ontentMDK:20249090 menuPK:64701643 pagePK:64141683 piPK:64141620 theSitePK:502184,00 $\underline{. \mathrm{html})}$.

${ }^{23}$ WB Directives contained both binding and non-binding elements, which lead to some confusion among staff, and a primary reason that was given for the OP/BP conversion process - see note 25 , below.

${ }^{24}$ See e.g., IFC definition: 'IFC's Performance Standards define clients' roles and responsibilities for managing their projects and the requirements for receiving and retaining IFC support. The standards 
comply and, thus, in a sense are 'binding' might be considered as 'upper tier' OP\&P. ${ }^{25}$ 'Staff guidelines' or 'guideline notes', 'practice notes', ${ }^{26}$ or 'best practices ${ }^{, 27}$ might be described as 'lower tier' OP\&P, since staff are encouraged to respect them (as they will arguably assist staff in making better operational decisions), but MDB staff are given discretion to deviate from these lower tier OP\&P. The significance of this hierarchy is also illustrated by differences concerning their formulation and enforcement, as the remaining sub-sections will illustrate. ${ }^{28}$

\subsection{Formulation, adoption and amendment}

The OP\&P are formally the products of the MDBs. Their staff compile drafts based on whatever input is deemed relevant (e.g., reports from quality assurance or operations evaluation departments and/or external sources such as civil society and

include requirements to disclose information.'

(http://www.ifc.org/ifcext/sustainability.nsf/Content/PerformanceStandards).

${ }^{25}$ Note that in terms of this hierarchy, the WB's OP/BP classification both fall within the top tier. Both OPs and BPs are 'binding' on staff and borrowers (as relevant); BPs contain more detail than their counterpart OPs. On criticism of the WB's reclassification process of Directives and Operational Policy Statements to the OP/BP structure, see e.g., P. Bosshard, J. Bruil, K. Horta et al., Gambling with People's Lives: What the World Bank's New "High Risk/High-Reward" Strategy Means for the Poor and the Environment, at 39 (2003); and see Clark 2002 at 221: 'The Bank's systematic process of weakening its policy framework represents another internal rebellion against the rule of law. The "reformatting" of Bank policies is generally viewed by these outside experts as an attempt to shield the Bank from accountability through the Inspection Panel process.'

${ }^{26}$ See e.g., IFC definition: 'The Guidance Notes are companion documents to IFC's Performance Standards and provide additional guidance to clients (and IFC staff) in fulfilling their roles and responsibilities under the standards.' (http://www.ifc.org/ifcext/sustainability.nsf/Content/PerformanceStandards).

${ }^{27}$ See e.g., the EBRD's description of its 'Sub-sectoral environmental and social guidelines': The EBRD has developed a set of sub-sectoral environmental and social guidelines to assist credit/investment officers in local financial institutions and other non-environmental experts. They are designed to help in identifying major environmental and social activity risks, important management actions, and essential aspects of environmental and social due diligence. The guidelines are not part of the Bank's Environmental and Social Procedures and are used as guidance only.' (http://www.ebrd.com/pages/about/what/policies/guidelines.shtml). Also see the AfDB's set of OP\&P, listing a mixture of 'policies' and 'guidelines' on their website: http://www.afdb.org/en/documents/policy-documents/guidelines-and-procedures/.

${ }^{28}$ See sections 2.2 and 2.3 below. 
academia). These draft new policies or proposed revisions of existing ones, particularly if they involve significant aspects of MDB operational policies (for example so-called 'safeguard policies') may be made available for public comment and then considered and formally adopted by the relevant internal organs, usually either the Bank's Board of Executive Directors, or its senior management, such as the Bank's chief executive officer. ${ }^{29}$

However, this formal position is being changed by evolving practice. While official adoption and amendment procedures remain intact, informal rule-making processes that involve extensive stakeholder participation are becoming more common, as the next section will illustrate.

\subsubsection{Evolving OP\&P review processes}

The lack of (effective) public participation in the review of existing OP\&P especially by those who are affected most by the OP\&P - has been a consistent point of criticism aimed at MDBs in the past (Kingsbury 1999, at 324-325; Boisson de Chazournes 1999). The MDBs have gradually started to respond to these comments, although not without eliciting additional criticism about the effectiveness of increased participation. The WB's revision of its Indigenous Peoples Directive in the 1990s, for example, was widely criticized for effectively 'watering down' policy requirements even though the Bank initiated a wide consultation process beforehand (Hunter at 199 in Bradlow \& Hunter (eds.) 2010). ${ }^{30}$

Notwithstanding the mixed success of stakeholder participation in past OP\&P reviews, a few noticeable trends can be discerned from more recent developments. The most evident observation is that most of the OP\&P revision processes currently underway or recently completed involved invitations for public participation as part of the review process. For instance, public participation was involved in the WB's

\footnotetext{
${ }^{29}$ E.g., most of the WB's OP\&P are issued 'under the authority of the [Bank's] President', by the relevant senior Bank management member (Shihata 2000, at 41).

${ }^{30}$ In addition, when the WB's Board of Directors reviewed the Resolution that established the Inspection Panel in 1996 and 1999, it involved external stakeholders in both instances - see Shihata 2000 at 155-203 and Bradlow 1999. Also note that the IMF has reviewed its conditionality policy a few years ago, for which it followed a public consultation process.
} 
recently concluded major revision of its Disclosure of Information Policy; ${ }^{31}$ in the IFC's current review of its Policy and Performance Standards on Social and Environmental Sustainability and Policy on Disclosure of Information (jointly known as its 'Sustainability Framework'), which is expected to be implemented by early $2011 ;^{32}$ in the AfDB's review of its accountability mechanism in June $2010 ; ;^{33}$ and was part of the IDB's review of its policy regulating its IAM in $2010^{34}$ and its Environment and Safeguards Policy between 2004 and 2006. ${ }^{35}$ The ABD's current review of its Accountability Mechanism Policy and Public Communication Policy (with target completion dates slated for the first half of 2011) provides for public participation; ${ }^{36}$ as does the EBRD's recent review of its IAM - re-launched in early 2010 as the 'Project Complaint Mechanism'. ${ }^{37}$ Public participation was also a feature of all nine completed WB policy reviews ${ }^{38}$ and its one ongoing review ${ }^{39}$ since 2002.

${ }^{31}$ Effective since 1 July 2010. The new policy makes a significant portion of documents available (e.g.,
minutes of Board meetings), and works on the principle that 'that the World Bank will disclose any
information in its possession that is not on a list of exceptions' (compared to working with a list of
documents that are available to the public). Another change of note is the possibility of appeal, should
an individual be refused access to a particular document. See WB Press Release No. 2010/448/EXC of 3 June 2010, New World Bank Access to Information Policy Takes Effect July 1 at http://web.worldbank.org/WBSITE/EXTERNAL/PROJECTS/EXTPOLICIES/EXTOPMANUAL/0,,co ntentMDK:22105228 menuPK:51455649 pagePK:64141683 piPK:64141620 theSitePK:502184,00. $\underline{\mathrm{html}}$.

${ }^{32}$ See http://www.ifc.org/policyreview.

${ }^{33}$ See http://www.afdb.org/en/about-us/structure/independent-review-mechanism/.

34 This review resulted in the replacement of the IDB's Independent Investigation Mechanism with the new Independent Consultation and Investigation Mechanism in February 2010 - see http://www.iadb.org/en/mici/independent-consultation-and-investigation-mechanism-mici,1752.html.

${ }^{35}$ See http://www.iadb.org/features-and-web-stories/2004-11/english/feedback-sought-on-new-idbenvironment-and-safeguards-policy-2179.html.

${ }^{36}$ See http://www.adb.org/AM-REview/. The ADB also revised the policy on their IAM substantially in 2001 - see Hunter at 226 in Bradlow \& Hunter 2010.

${ }^{37}$ For more detail on enforcement-related changes made to the EBRD's IAM, see section 3.2 below.

${ }^{38}$ I.e., Adjustment Lending to Development Policy Lending (2002-04); Conditionality (2007); Country Systems in Bank-Supported Operations (2007); Governance and Anticorruption (GAC) (2006-2007); GAC Implementation Plans (2007); Monitoring and Evaluation Policy (2006); Eligibility of Expenditures in World Bank Lending (2003-04); Use of Country Systems for procurement (2008); and the Volcker Report on Department of Institutional Integrity (2007). 
In general these OP\&P reviews seem to be the result of the institutions' genuine need for their OP\&P to reflect evolving practice and the realization that the content of the OP\&P has to be updated and refined in the light of the lessons in MDB operations. The relevance of public participation in this process is reflected in this WB statement:

The World Bank solicits feedback from different stakeholders prior to the adoption of new or significantly changed sector or thematic strategies, policies or other documents that affect Bank operations. The objectives are to capture the experience and knowledge of various audiences, to give voice to the poor, and to increase transparency and citizen involvement in development decision making [...]. Through consultations, the World Bank Group is able to tap into a broad range of perspectives. It strives to integrate comments and new ideas into its operations, policies and final documents. ${ }^{40}$

This statement also highlights that fact broad stakeholder participation, in fact, is becoming a regular part of the review process. All OP\&P revisions identified above involve(d) extensive, pre-announced consultation programmes involving external stakeholders, over extended periods of time. ${ }^{41}$

The IFC's review of its Sustainability Framework serves as a particularly good example. ${ }^{42}$ A separate section of the IFC's website has been dedicated to the review, with the timeline, consultation process, milestones and outcomes clearly defined, and all (interim) documentation surrounding the review easily accessible. Consultation is opened to any party, which can register for various sessions held around the world

39 I.e., the World Bank's Whistle-blowing Policy, available at http://web.worldbank.org/WBSITE/EXTERNAL/NEWS/0,,contentMDK:21624514 pagePK:6425704 3 piPK:437376 theSitePK:4607,00.html.

40

http://web.worldbank.org/WBSITE/EXTERNAL/PROJECTS/0,,contentMDK:21807601 menuPK:506 8208 pagePK:41367 piPK:51533 theSitePK:40941,00.html. MDBs have also become increasingly convinced of the link between 'process rights and development effectiveness' - see Hunter in Bradlow \& Hunter 2010, at 209-211.

${ }^{41}$ For a description of an evolving eight-stage policy-making process, see Hunter in Bradlow \& Hunter 2010 , at 223-232.

${ }^{42}$ See above, note 32 . 
during each stage of the three-phased process, ${ }^{43}$ and comments on draft policy versions from previous stages of the process are facilitated via the website. ${ }^{44}$

To conclude, while public participation in these rule-making processes has still not been formalized or 'codified' in a 'policy about policies', ${ }^{45}$ current OP\&P reviews seem to have embedded stakeholder consultation in MDB practice.

\subsection{Enforcement mechanisms}

All MDBs have established fairly extensive institutional frameworks to ensure consistent enforcement of the OP\&P throughout their institutions and across all their borrowers. For instance, a variety of internal bodies have been put in place to ensure institutional compliance, such as departments charged with ensuring more systemic compliance $^{46}$ (e.g., evaluations departments that take a retroactive view and quality assurance departments that take a proactive view on compliance performance of individual projects) and others mandated specifically to investigate specific instances of alleged non-compliance (e.g., institutional integrity units and IAMs through their compliance functions, although non-compliance might also come to light in the course of their problem solving stages). ${ }^{47}$ As far as the institutional mandate of the IAMs is concerned, it is important to note that it is usually limited to 'upper level' OP\&P (or certain subsets within it, such as safeguard policies). ${ }^{48}$ Hence, it is controversial when an MDB 'deregulates' certain aspects of a policy to the 'lower level' OP\&P as it effectively narrows the IAM's enforcement mandate. ${ }^{49}$

\footnotetext{
${ }^{43} \mathrm{http}: / /$ www.ifc.org/ifcext/policyreview.nsf/Content/ConsultationEventsRegistration.

${ }^{44} \mathrm{http} / / / \mathrm{www}$.ifc.org/ifcext/policyreview.nsf/Content/ProvideInput.

${ }^{45}$ For arguments supporting the 'codification of administrative procedures at IFIs', see Hunter in Bradlow \& Hunter 2010, at 232-237.

${ }^{46}$ Interestingly, the WB is currently conducting a review of all five of its internal independent evaluation and review mechanisms.

${ }^{47}$ IAMs, with the exception of the WB's IP, typically fulfil two functions: dispute-resolution in a 'problem-solving phase' and compliance assurance in a 'compliance phase' - see Bradlow \& Naudé Fourie, in Hale \& Hand (eds.) forthcoming.

${ }^{48}$ E.g., the WB IP Mandate's specifically excludes the Best Practice Guidelines 'and similar documents or statements' (Inspection Panel 1993 Resolution, para. 12); however, all IAMs' mandates cover 'safeguard or sustainable development' OP\&P (see above, section 2.1.1).

${ }^{49}$ See above, note 25 .
} 
A point of criticism made in this context has been the lack of internal sanctions used against Bank staff in cases of proven non-compliance, especially in cases of findings more systemic non-compliance. ${ }^{50}$ While this is a valid concern as it points to the question of the effective functioning of IAMs and to MDB staff and management's perception of the IAMs, this criticism must be viewed in context. Although it is certainly possible that there are cases of 'repeat offenders' among staff, it is more likely that the major problems concerning OP\&P compliance arise from the complexity of the projects being funded by the MDBs, staff uncertainty about how to apply the policies (which, in turn, is sometimes caused by mixed messages from management), ${ }^{51}$ gaps in the available knowledge, or staff succumbing to time and cost pressures.

Borrower compliance with OP\&P, on the other hand, is generally ensured by (the threat of) legal sanctions (such as suspension of loan disbursements, or withdrawal of the loan) since the relevant OP\&P are typically incorporated into the loan agreement between bank and borrower. MDBs have been criticized in the past for not employing these enforcement strategies in face of glaring borrower noncompliance; or at least not consistently, leading to the unequal treatment of borrowers. $^{52}$

Interestingly, all MDBs specifically mention their public information disclosure policies as a crucial element of their compliance framework - the logic being that increased transparency (and the increased public scrutiny following from this) leads to better conditions for ensuring institutional compliance with OP\&P. The trend certainly has been to disclose more information over the years. In fact, the WB's recently amended 'Access to Information Policy' adopted an even broader approach:

\footnotetext{
${ }^{50}$ An exception would be institutional integrity cases where individuals are held accountable for fraud allegations, etc.

${ }^{51}$ E.g., in the WB IP's 1999 China Western Poverty Reduction Project case, the Panel noted 'an unusually and disturbingly wide range of divergent and, often, opposing views' between Bank staff including senior management - 'on how the Bank's operational policies and procedures should be applied.' (IR (ES), para. 9).

${ }^{52}$ See below, note 68. The WB's IP also picked up on this problem in the 1999 China Western Poverty Reduction Project case, noting recurring staff opinions that 'in China things are done differently' (IR (ES), para. 14).
} 
project-related information is in principle available to the public, with the exception of a few specific documents. ${ }^{53}$

Clearly, as have been illustrated by some of the examples mentioned above, the mere existence of such enforcement mechanisms says very little about their effectiveness. This issue, and particularly the role that IAMs are playing in the realizing the enforcement potential of the OP\&P, will be discussed in more detail in the next section.

\section{Strengthening the normative significance and enforcement potential of the OP\&P}

This report argues that, although there remains much scope for improvement, ${ }^{54}$ the normative significance and enforcement potential of the OP\&P at MDBs are being strengthened as a result of three major developments in the evolution of the OP\&P, namely: increased public scrutiny of the OP\&P through enhanced stakeholder participation in the OP\&P review process (discussed in section 2.2.2. above); a "hardening" of the OP\&P as a result of IAM compliance procedures (discussed in section 3.1 below); and ongoing institutional development occurring at most IAMs, resulting in a potential enhancement of their enforcement role (discussed in section $\underline{3.2}$ below).

\section{1 “Hardening" the OP\&P through IAM compliance procedures}

The potential of the OP\&P to evolve into more than mere norms that promote better standards in MDB operations has long been recognised (Kingsbury 1999), which means that they can be used to hold MDBs responsible for their actions and even contribute to the normative development of international law in particular areas. This conclusion followed from the fact that the IAMs, in exercising their compliance review mandates, ${ }^{55}$ logically had to interpret the OP\&P in order to determine whether or not the MDBs have been in compliance with the provisions in question.

\footnotetext{
${ }^{53}$ See above, note 31 .

${ }^{54}$ See section 4 below.

${ }^{55}$ This section will focus on the compliance procedures / phases of the IAMs, not the problem-solving phase that usually precedes it.
} 
Prior to the establishment of the IAMs, this interpretative function was the exclusive responsibility of the MDB management and staff, including the Banks' legal departments, which would be asked to interpret the policies whenever a particular issue implicated the Bank's legal obligations. ${ }^{56}$ The establishment of the IAMs created the potential for the IAMs and the Management and staff to follow different interpretations of the OP\&Ps, which are drafted in relatively broad language and often without great detail or precision on how they should be applied. These differences in interpretation compel the institutional entity responsible for final approval of the IAM's compliance review reports (usually, the Bank's Board of Executive Directors) to decide which OP\&P interpretation to accept. This is a new function for the MDB's Boards of Directors and has created a challenge for them because they often feel ill-equipped to choose between the different interpretations.

However, as we will illustrate below, it can be argued that the IAMs' interpretations of particular OP\&P have come to carry increasing weight within the institutions, especially in the World Bank context (Shihata 2000; Naudé Fourie 2009, at 193-250). We suggest that the primary contribution of the IAMs in enhancing the normative significance of the OP\&P is their 'hardening' or, 'legalization' of the OP\&P through the exercise of their compliance review mandate. ${ }^{57}$ Such a claim is potentially difficult to substantiate without employing a sound analytical framework, such as the conceptual model describing the legalization process developed by Abbot et al. This model identifies three dimensions of legalization, namely: 'obligation' (the extent to which an actor is 'legally bound by a rule or commitment in the sense that their behavior thereunder is subject to scrutiny under the general rules, procedures, and discourse of international law'); 'precision' (whether the 'rules unambiguously define the conduct they require, authorize, or proscribe'); and 'delegation' (i.e., third parties have been granted authority to implement, interpret, and apply the rules; to

\footnotetext{
${ }^{56}$ IAMs have to consult Bank's legal department about interpretation of OP\&P, but only when it's a question of MDB legal obligations. See e.g., WB IP 1999 Resolution, para. 15.

${ }^{57}$ Note that the term 'legalization' does not necessarily have a positive connotation in the IAM context. During the early years of the WBIP, the Panel - and external commentators - often accused Bank management of being overly 'legalistic', i.e., formalistically sticking to the letter of the IP Resolution or specific OP\&P provisions. See e.g., See 1995 Tanzania Power IV Project, ER, at para. 8; 1996 Paraguay/Argentina Yacyretá Hydroelectric Project, Review \& Assessment, at 48-49; and 2005 Cambodia Forest Concession Management and Control Pilot Project, IR (ES) at 22-23.
} 
resolve disputes; and (possibly) to make further rules') (Abbot et al., in Goldstein et al. (eds.) 2001, at 17-34). Moreover, the model contends that each of these dimensions form a continuum, which allow for relative comparisons between different norms and (quasi-) legal entities responsible for normative development - see Figure 1 below.

Figure 1: Dimensions of legalization

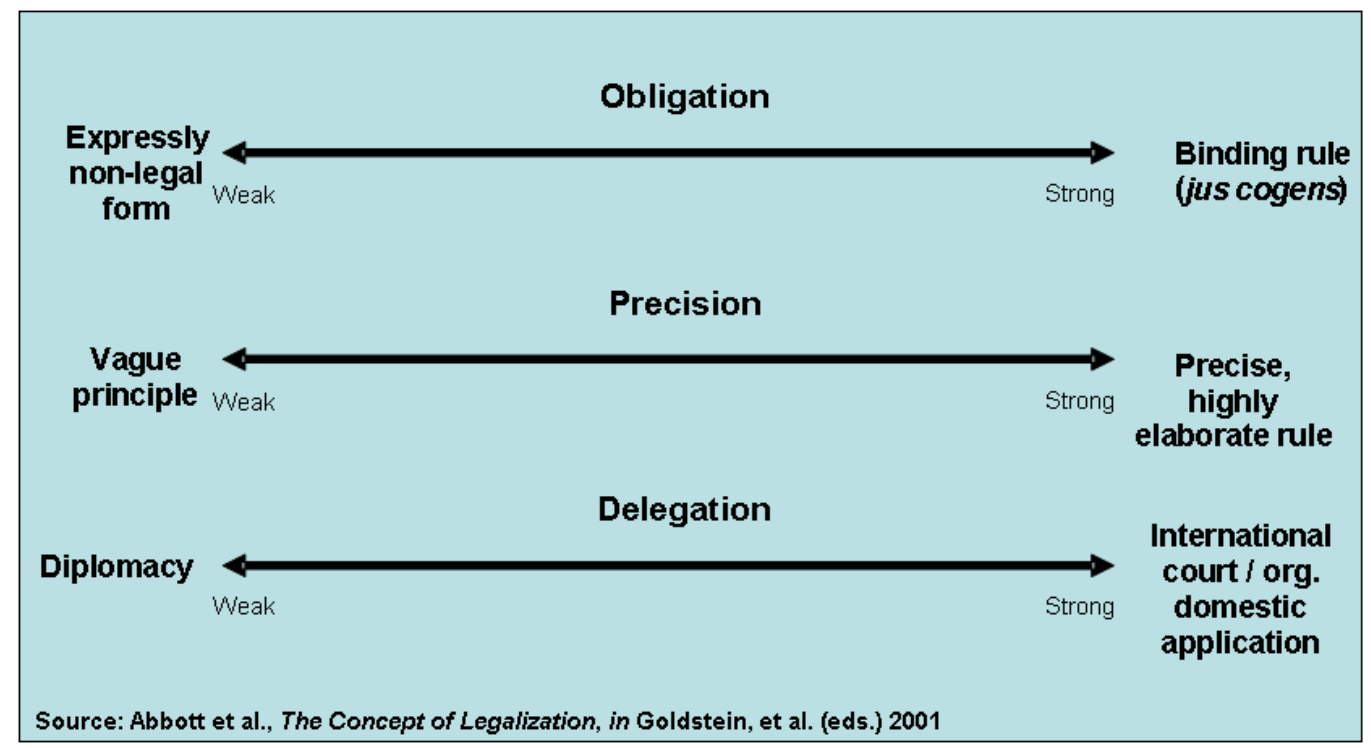

We use this model to analyse the extent to which the IAMs have "legalized" the OP\&P. In other words: are the IAMs contributing to the strengthening of the OP\&P from expressly non-legal forms to stronger, binding rules (obligation)? Are they strengthening particular OP\&P provisions from being vague principles to stronger elaborate rules (precision)? And are the IAMs, through their persistence in interpreting the OP\&P, also gradually moving the MDBs to accept a model where the normative development of the OP\&P is increasingly being entrusted to the IAMs (delegation)?

It might be argued that the IAMs have had an insufficient number of compliance reviews ('jurisprudence') to answer these questions conclusively. This is particular applicable to the IAMs at the regional development banks, most of which have recently undergone institutional review and reform (as section 3.2 will elaborate). The World Bank's Inspection Panel (WBIP), on the other hand, which has been active since 1994 and has not undergone an institutional review since 1999, has 
accumulated a fair number of compliance review cases. ${ }^{58}$ The Panel has furthermore been the subject of a fair amount of research. The remainder of this section will therefore use the WBIP as basis for the analysis.

\subsubsection{Illustrative: The World Bank's Inspection Panel}

\section{Strengthening the obligatory nature of OP\&P}

It appears that substantial confusion exists among WB Bank staff, management and Board members about the nature of OP\&Ps: are they 'strict marching orders' to be closely followed by Bank staff and borrowers, ${ }^{59}$ or do they allow for considerable leeway, or 'managerial discretion'? ${ }^{60}$ This uncertainty was clearly demonstrated in the IP's landmark China Qinghai case (1999-2000). The Panel acknowledged that the OP\&P (most still styled as 'directives' at that point) did allow for some managerial discretion, but insisted that

the directives cannot possibly be taken to authorize a level of "interpretation" and "flexibility" that would permit those who must follow these directives to simply override the portions of the directives that are clearly binding. ${ }^{61}$

WB management in turn criticized the Inspection Panel's position, arguing that '[m]any of the Panel's findings appear [...] to be based on an application of elements of each policy as legally binding rules, allowing for little or no flexibility or room for judgement ${ }^{62}$ The case itself did not put a conclusive end to the debate, but it proved to be indicative of what was to come: while the Bank continued to clarify the obligatory nature of its OP\&P through the so-called conversion process into

\footnotetext{
${ }^{58}$ As of March 2010, the WBIP has registered 71 compliance review cases. Compare this with the ADB (3 compliance review cases since 2003); IDB (7 compliance review cases in total); AfDB (6 requests for both compliance reviews and problem solving); and EBRD (4 requests since new mechanism was adopted in 2010). The possible exception would the IFC's CAO, which, as of March 2011, has registered over 50 cases (with 11 cases going to compliance review) since its inception.

${ }^{59}$ Shihata 2000, at 41-49.

${ }^{60} 1999$ China Western Poverty Reduction Project, IR (ES), at para. 15.

${ }^{61} 1999$ China Western Poverty Reduction Project, IR (ES), at para. 11.

621999 China Western Poverty Reduction Project, MR, at paras. 2.2.2 \& 2.4; and MR to IR, at para. 20.
} 
OP/BP/GP, ${ }^{63}$ the Panel persisted in its approach of setting out the contours of managerial discretion - as the next point will illustrate.

The language of some of the OP\&P makes it clear that they allow for some 'professional judgement' or 'managerial discretion'. ${ }^{64}$ On the one hand, this flexibility in the text allows the IP to adopt expansive interpretation techniques. ${ }^{65}$ On the other hand, it erodes the obligatory nature of the OP\&P. There are numerous examples in the IP's investigation reports of instances where the IP has explicitly delineated (and as a practical result, effectively limited) management discretion. For instance, the IP repeatedly rejected WB management's arguments that the exercise of its legal remedies against the borrower was 'not a requirement but a discretionary tool, to be applied only after other reasonable means of persuasion have failed'; ${ }^{66}$ or that it was 'a matter for the judgment of Management, taking into account all the circumstances of each case', and that a decision not to suspend loan disbursements, for example, was 'neither a sign of negligence nor of lack of concern'. ${ }^{67}$ The IP rejected these arguments in a number of cases, countering that its founding Resolution explicitly listed as 'an instance of failure in the compliance of Bank policies and procedures situations where the Bank has "failed in its follow-up on the borrower's obligations under loan agreements with respect to such policies or procedures". ${ }^{68}$ Another example where the Panel has repeatedly challenged Managerial discretion, and thus strengthened the obligatory nature of the relevant provisions, concerns the environmental screening of projects. Over the years, the Panel has questioned the screening of several projects that Bank Management has deemed to be lower risk ('category B') and found the project to be in non-compliance with the relevant OP\&P

\footnotetext{
${ }^{63}$ See above, note 25 .

${ }^{64}$ See below, note 72 .

${ }^{65}$ See Naudé Fourie 2009, at 231-244.

${ }^{66} 1996$ Paraguay/Argentina Yacyretá Hydroelectric Project, MR, at para. 1.8.

${ }^{67} 1997$ India NTPC Power Generation Project, MR, at 3. Also see 1995 Brazil Rodônia Natural Resources Management Project, MR, at para. 4.

681996 Paraguay/Argentina Yacyretá Hydroelectric Project, ER, at paras. 30-31. Also see 1995 Brazil Rodônia Natural Resources Management Project, Additional Review, at paras. 55-56; 1997 India NTPC Power Generation Project, MR, at para. 3. Compare to 2004 India Mumbai Urban Road Transport, where the Bank exercised one of its legal rights (suspension of funds) in the light of the Inspection Panel's findings (India Mumbai Urban Road Transport, MR to IR, at para. 89).
} 
since it should have been classified as a higher environmental risk project ('category $\left.\mathrm{A}^{\prime}\right) .{ }^{69}$ Importantly, the IP rejected Bank management's claim that the environmental screening of projects was solely a management prerogative for which there cannot be a consistent interpretation, since

[s]creening a project into either Category A or B requires judgement about the overall risks (type of project, location, environmental sensitivity) of the project as well as the nature and magnitude of potential impacts. How the risks and impacts are judged depends on the specific project involved. ${ }^{70}$

The Panel's consistent counterargument has been that the appropriateness of a particular environmental screening depended on a 'straightforward' interpretation of the particular OP\&P provisions, which was exactly what the Panel did when it conducted its compliance review. ${ }^{71}$

\section{$\underline{\text { Adding to the precision of particular OP\&P provisions }}$}

Like all rules with normative content, OP\&P contain concepts and phrases that are (often deliberately) vague - i.e., they require interpretation in order to strengthen their precision with regards to a particular case or in order to have broader application. ${ }^{72}$

${ }^{69}$ See e.g., 1999 China Western Poverty Reduction Project; 2004 Pakistan National Drainage Program Project; and 2005 Cambodia Forest Concession Management and Control Pilot Project. There were also a number of projects where the IP concurred with Management's project classification, although it specifically reviewed whether the classification was in line with the OP\&P in those instances - see e.g., 1999 Kenya Lake Victoria Environmental Management Project (the Panel concurred with Management's categorization of 'B'); 1999 Ecuador Mining Development and Environmental Control Technical Assistance Project (the Panel concurred with Management's categorization of 'A'); 2001 Chad Petroleum Development \& Pipeline Project (the Panel concurred with Management's categorization of 'A'); 2001 Uganda Third Power Project, Fourth Power Project, and proposed Bujagali Hydropower Project (the Panel concurred with Management's categorization of 'B'); and 2004 Colombia Cartagena Water Supply, Sewerage and Environmental Management Project (the Panel concurred with Management's categorization of 'A').

701999 China Western Poverty Reduction Project, Request, at 4; and MR, at 64

${ }^{71} 1999$ China Western Poverty Reduction Project, IR, at para. 152.

${ }^{72}$ Consider, e.g., these phrases from OP\&P: '[t]he Bank favors preventive measures over mitigatory or compensatory measures, whenever feasible' (OP 4.01 (Environmental Assessment), at para. 2 (emphasis added); and 'the Bank satisfies itself that the borrower has explored all viable alternative project designs to avoid physical displacement of these [indigenous] groups. When it is not feasible to 
The IP's growing jurisprudence is making a significant contribution to making several of these concepts and phrases more precise, and thereby also clarifying the obligations of the WB towards PAP. For instance, the phrase 'meaningful and informed consultation' comes up in several of the Bank's OP\&P, and has lead to misunderstandings and widely differing expectations between Bank staff and PAP. ${ }^{73}$ Over the years, the Panel has shaped the substantive and procedural content of this phrase, often describing what it was not. ${ }^{74}$ Specifically, the Panel ruled on several occasions that it wasn't good enough for Bank management merely to confirm that consultation "has taken place ${ }^{75}$ as the content of those consultation sessions were of paramount importance. For instance, 'information sessions' did not constitute 'meaningful consultations'. As the Panel commented in the 1999 Ecuador Mining Development case:

It is worth noting that Management does not categorize these meetings 'to consult' but rather as meetings "to inform" [...]. In the Panel's view, Management's approach to consultation was unfortunate. If there was proper CONSULTATION, "[c]onducted in the spirit of the OD”, Management could have addressed these concerns long ago or prevented many of the issues raised by the Requesters. ${ }^{76}$

The very notion of 'compliance' is another example where the IP added a degree of precision through its substantive and procedural development of the

avoid such displacement, preference is given to land-based resettlement strategies [...].' (OP 4.12 (Involuntary Resettlement), at para. 9 (emphasis added).

${ }^{73}$ See e.g., 1999 Ecuador Mining Development and Environmental Control Technical Assistance Project, IR paras. 52, 57 \& 103; 2001 India Coal Sector Environmental and Social Mitigation Project and Coal Sector Rehabilitation Project, IR, at paras. 421 \& 437; and 2004 Colombia Cartagena Water Supply, Sewerage and Environmental Management Project, IR (ES), at 21 and IR, at para. 240.

${ }^{74}$ E.g., consultations could not take place in the presence of government officials and armed guards (1999 China Western Poverty Reduction Project, Request, at 9; MR, at 74-75; and IR, at para. 116; and 2001 Chad Petroleum Development \& Pipeline Project, IR (ES), at paras. 26 \& 37); and surveys used in the consultation process had to guarantee the anonymity of participants (1999 China Western Poverty Reduction Project, IR, at para. 116).

751999 China Western Poverty Reduction Project, IR, at para. 116.

${ }^{76} 1999$ Ecuador Mining Development and Environmental Control Technical Assistance Project, IR, at paras. 52, 57 \& 103 (emphasis, in bold, in the original). Also see 2004 India Mumbai Urban Transport Project, IR, at para. 372; and 2001 India Coal Sector Environmental and Social Mitigation Project and Coal Sector Rehabilitation Project, IR, at para. 421. 
concept. In essence, the Panel argues that a mere 'process' or formalistic approach to compliance is typically not enough to ensure that a project is compliant with an OP\&P. For example, an environmental assessment that meets all the formal criteria set out in the OP\&P could still be inadequate when the substantive quality is taken into account. As the Panel concluded in the China Qinghai case:

[...] in appraising compliance, Management had an obligation to satisfy itself not only that the process and procedures mandated by the policies had been followed, but also that the work under review met professionally acceptable standards of quality. In other words, both process and quality were essential components of compliance. ${ }^{77}$

\section{Strengthening the delegation of interpretative functions}

This dimension of legalization is arguably the weakest of the three since the IP is not solely tasked with providing authoritative interpretations of the OP\&P; and, as many of the examples mentioned in this section illustrated, Bank management and the IP frequently supports entirely opposite interpretation. Formally speaking, the interpretation that stands will be the one accepted by the Bank's Board of Executive Directors. However, to the extent that the Board continues its practice of usually accepting the Inspection Panel's Investigations Reports without specific comment, this procedure does not necessarily clarify the particular position. ${ }^{78}$ Whether Bank management and staff actually accept the delegation of interpretative functions to the IP might also be questioned, as the phenomenon of 'panel proofing' (i.e., actions taken by Bank staff simply to avoid or limit an Inspection Panel investigation) illustrates. $^{79}$

On the other hand, it can be argued that the Panel's interpretations of OP\&P have steadily gained in credibility over the years - compare, for instance, earlier Management Responses (MR) to IP investigation reports (where most Panel findings were rejected, with very little remedial action being proposed or undertaken by the Bank in light of the IP reports) with later MRs that acknowledge most Panel

\footnotetext{
771999 China Western Poverty Reduction Project, IR, at paras. 180- 186.

${ }^{78}$ See e.g., Shihata 2000, at 37-41 on early controversy regarding the meaning of the word 'project' in the IP Resolution (which affected the scope of the IP's mandate).

${ }^{79}$ E.g., Clark 2002, at 221-222; and see in general, Fox 2000. On panel proofing, also see note 25, above.
} 
findings. ${ }^{80}$ Or consider Management's proposals to engage in discussion with the IP on what 'compliance' might mean in certain circumstances:

[i]n conducting EAs, the question of how much data is enough frequently arises, given the need to make case-by-case judgments on the type and amount of data to be collected [...]. In the case of the pipeline, Management considered the trade-offs, because the data collected did provide a sufficient basis for mitigative measures through the EASs and for monitoring. In the context of the Pipeline Project, Management would welcome an occasion to exchange views with the Inspection Panel on what should constitute adequate data collection. ${ }^{81}$

Regardless of which of the two positions is a more accurate reflection of the internal perception at the Bank, it can be said with certainty that the IP's interpretations of the OP\&P have come to serve as the benchmark for shaping PAP and their representative's expectations concerning their rights vis-à-vis the Bank.

\subsection{Enhancing enforcement potential through institutional reforms of IAMs}

A consistent criticism of the WBIP process has been the lack of formalized Panel and Requester involvement in the development and implementation of Management remedial action plans (i.e., strengthening of the 'enforcement' elements of the process). ${ }^{82}$ It is one matter to find, often pervasive, occurrences of non-compliance with OP\&P; it is another matter altogether to ensure that those specific instances are

\footnotetext{
${ }^{80}$ Compare e.g., the MR in 2001 India Coal Sector Environmental and Social Mitigation Project and Coal Sector Rehabilitation Project (see MR to IR, Annex 1 - where Management 'noted' the Panel's findings of non-compliance in many instances, but concluded that there was 'no action to be taken' or that the Bank would 'continue supervision' - see e.g., action numbers 1, 3, 4, 10, 11, 12, 13, 14, 17, 21, 22, 23, 24, 26, 28, 31), with later MRs such in 2004 Pakistan National Drainage Program Project (e.g., in this case, Management acknowledged that categorizing the project as a 'category B' for environmental assessment purposes was 'premature' and 'that it would have been more appropriate to categorize this as an EA category “A” project.' (MR, at para. 43)); and 2005 Cambodia Forest Concession Management \& Control Pilot Project (where 'Management acknowledges that the project did not succeed in adequately addressing the concerns of local communities and Indigenous Peoples.' (MR to IR, at para. 23)).

${ }^{81} 2002$ Cameroon Petroleum Development and Pipeline Project, and Petroleum Environment Capacity Enhancement Project, MR to IR, at para. 28 (also see para. 23 for another example).

${ }^{82}$ See Horta 2002. This criticism is also echoed in the comment that new accountability mechanisms do little to provide claimants with real redress or remedies - see e.g., Wellens 2002, at 266-267.
} 
remedied, and even more so if the non-compliance point to systemic policy failures. In the case of the WBIP, no such enforcement role was foreseen for either the Panel or the claimants. In fact, the Bank's Board has emphatically decided to stop Panel involvement post the delivery of the Investigation Report (which had developed in practice) ${ }^{83}$ Yet, practice has continued to evolve in a different direction - albeit at the discretion of the Bank's Board. For instance, the Board has formally requested the Panel to remain engaged in the remedial phase in controversial cases such as 2002 Paraguay / Argentina (Yacyretá) and 2004 India Mumbai Urban Road Transport; while a recently implemented section on the IP's website ('Post-Investigations Progress Reports and Actions') list current IP post-investigation involvement in nine cases. $^{84}$

Over time, the other MDBs have enhanced the enforcement potential of their respective IAM and the original complainants. The IFC's Compliance Advisory Ombudsman, for example, is specifically tasked with an enforcement role, ${ }^{85}$ and the IDB's accountability mechanism may get involved in post-investigation monitoring at request of the Board, ${ }^{86}$ while the AfDB's IAM is permitted to make recommendations regarding potential remedies, although it has no formal enforcement role. ${ }^{87}$

\footnotetext{
${ }^{83}$ See 1999 Board Review Conclusions, at para. 16: 'The Board should not ask the Panel for its view on other aspects of the [Bank management] action plans nor would it ask the Panel to monitor the implementation of the action plans.'
}

84

http://siteresources.worldbank.org/EXTINSPECTIONPANEL/Resources/PostInvestions_Progress_Rep orts_and_actions_July_2010.pdf, accessed 14 March 2011. The Panel's website also shows 'follow up report' in several other older cases - see e.g., 1995 Brazil Rondônia Natural Resources Management Project (progress report in 1997); 1996 Bangladesh Jamuna Multipurpose Bridge Project (progress report in 1998); and 2004 Colombia Cartagena Water Supply, Sewerage and Environmental Project (progress report $\quad$ in 2006) http://web.worldbank.org/WBSITE/EXTERNAL/EXTINSPECTIONPANEL/0,,contentMDK:2022160 6 menuPK:4766130 pagePK:64129751 piPK:64128378 theSitePK:380794,00.html.

\footnotetext{
${ }^{85}$ See http://www.cao-ombudsman.org/howwework/compliance/.

${ }^{86}$ Para. 72, Policy Establishing the Independent Consultation and Investigation Mechanism of 17 February 2010, available at http://www.iadb.org/en/mici/independent-consultation-and-investigationmechanism-mici, 1752.html.

${ }^{87}$ Paras. 52(c) and 60, The Independent Review Mechanism, Operating Rules and Procedures of 16 June 2010, available at http://www.afdb.org/en/about-us/structure/independent-review-mechanism/.
} 
However, at this moment, recent institutional reforms of the EBRD's Project Complaint Mechanism (PCM) appear to go furthest in enhancing the enforcement potential of the IAM. For instance, in the course of processing a complaint the 'Project Complaints Mechanism Officer' (PCM Officer) can make an interim recommendation to the relevant EBRD body to suspend Bank payments, ${ }^{88}$ in cases of non-compliance findings, compliance review experts are specifically required to make recommendations to

a. address the findings of non-compliance at the level of EBRD systems or procedures to avoid a recurrence of such or similar occurrences; and/or

b. address the findings of non-compliance in the scope or implementation of the Project taking account of prior commitments by the Bank or the Client in relation to the Project; and

c. monitor and report on the implementation of any recommended changes. ${ }^{89}$

while the PCM Officer is specifically tasked with monitoring 'the implementation of the recommendations of the Compliance Review Report subject to the timetable and estimate of human and financial resources as set in the Management Action Plan'. ${ }^{90}$ Moreover, complainants are given the opportunity to comment on the Compliance Review Report and the Management Action Plan, and those comments are also included in the final set of reports ultimately submitted to the Bank's Board. ${ }^{91}$

Clearly, further research into this area is required - especially into the growing body of 'jurisprudence' of the IFC's CAO, the IDB's MICI, the ADB's AM, the AfDB's IRM, and the EBRD's PCM - before any definitive conclusions can be drawn. What is clear, however, is that the evolving enforcement role of the IAMs at MDBs has the potential to further strengthen the normative development of the OP\&Ps, and to further clarify MDB obligations vis-à-vis a variety of stakeholders.

\section{Preliminary observations}

This report provided an overview of the content, formulation, adoption, amendment and enforcement of OP\&P at the MDBs. It highlighted the impact of three recent

\footnotetext{
88 Para. 30, Project Complaint Mechanism, Rules of Procedures of, available at http://www.ebrd.com/pages/project/pcm/about.shtml.

${ }^{89}$ Para. 40, id.

${ }^{90}$ Para. 44, id.

${ }^{91}$ Paras. 42 \& 43, id.
} 
developments that are strengthening the normative significance and enforcement potential of the OP\&P, namely: broadening stakeholder participation in OP\&P revision processes; 'hardening' or legalization of OP\&P through IAM compliance procedures; and emerging enforcement potential of the IAMs.

This section will set out a few preliminary observations drawn from the report; and explore potential implications for IO responsibility.

i) All OP\&P, in principle, are in the public domain and have become increasingly accessible to the general public through their publication on the internet. While this degree of transparency is commendable, locating complete catalogues of OP\&P on the websites of the MDBs is not necessarily a straightforward exercise - and almost certainly not for all people affected by MDB development projects (including their civil society allies) who increasingly consult the OP\&P as a means of ascertaining their 'rights' against the MDBs (Hunter 2003. at 204). Given the growing importance of the OP\&P for external parties, and not only for internal staff members and borrowers, the MDBs should ensure that the OP\&P are located in more prominent areas of their websites - the layout of which, in fairness, continues to be improved on a regular basis.

ii) The MDBs have been making significant progress in facilitating broad stakeholder participation in their OP\&P review processes; however, such participation remains at the discretion of the MDB, and has not been formalized (or, 'codified'), for example, through the adoption of a 'policy about policies'. ${ }^{92}$ We suggest that this should be a logical next step now that the practice of stakeholder participation in OP\&P reviews have become more firmly embedded in the institutional culture.

iii) The ongoing normative development of OP\&P is fuelled by public participation in review processes and by the ability of non-state actors to

\footnotetext{
${ }^{92}$ To some extent, some policies establishing the IAMs would seem to be an exception - see e.g., para. 69 of the EBRD's Project Complaint Mechanism's Rules of Procedure: 'The PCM will be reviewed by the Board every three (3) years or as needed.' And see para. 99 of the IDB's Policy Establishing the Independent Consultation and Investigation Mechanism: 'Two (2) years after the effective date of the Mechanism, the Board shall request an independent evaluation of the Mechanism. On the basis of such evaluation, and any comments thereon from Management, the Board will assess the experience with Mechanism.'
} 
initiate the compliance procedures of IAMs. Both are driving the strengthening of the obligatory nature of the OP\&Ps and the clarification of substantive and procedural MDB obligations - especially towards third parties in a non-contractual relationship with them.

iv) A key area for future development with regards to OP\&P rule making procedures, as well as the effective implementation / 'operationalization' of the O\&P\& at MDBs, concerns the further enhancement of the IAMs' enforcement role. Currently, their enforcement role, if it exists at all, is limited to making recommendations and monitoring the implementation of the remedial action plan developed by the Bank Management.

v) The evolution of OP\&P at the MDBs, and the role played by the IAMs in this regard, potentially hold broader implications for ensuring IO responsibility, and for international law as a whole. For instance:

- Given the significance of MDBS in the international arena (the WB and IFC in particular), current OP\&P review processes may be developing rules for public participation at the international level - 'administrative' rules which appear to be lacking or, at least underdeveloped in conventional international law discourse.

- The normative development of the substantive and procedural aspects of legal concepts and constructs such as 'consultation' and 'compliance' through IAMs enforcement processes, for instance, has potential value beyond the MDB context.

- Since the OP\&P also deal with issues that raise important international law questions - such as rights of indigenous people, compensation for involuntarily resettled people, the responsibilities of actors for the environmental consequences of their actions - their formulation and interpretation can contribute to the development of international law on these issues. It remains noticeable, however, that the IAMs continue to make scant references to existing international legal standards and soft law - which, arguably weakens its broader contribution to international law.

- Since MDBs are not the only IOs that are engaged in actions that directly affect the citizens of their member states (other examples are the UN's operations relating to refugees, humanitarian assistance, governance), the 
example of the IAMs at multilateral development banks sets standards for accountability and responsibility of IOs that has relevance for all IOs. 


\section{References}

G. Alfredsson \& R. Ring, The Inspection Panel of the World Bank: A Different Complaints Procedure, The Hague: Martinus Nijhoff Publishers (2001)

J. E. Alvarez, International Organizations as Law-makers, Oxford: Oxford University Press (2005)

P. Bosshard, J. Bruil, K. Horta, S. Lawrence \& C. Welch, Gambling with People's Lives: What the World Bank's New “High Risk/High-Reward” Strategy Means for the Poor and the Environment, Environmental Defense, Friends of the Earth and International Rivers Network (2003)

D. Bradlow, Precedent-Setting NGO Campaign Saves the World Bank's Inspection Panel, 6 Human Rights Brief 7 (1999)

D. Bradlow, Private Complainants and International Organizations: A Comparative Study of the Independent Inspection Mechanisms in International Financial Institutions, 36 Georgetown Journal of International Law 403 (2005)

Daniel D. Bradlow \& David Hunter (Eds.), International Financial Institutions \& International Law, Alphen aan den Rijn: Kluwer Law International (2010)

D. Bradlow \& A. Naudé Fourie, Independent Accountability Mechanisms at International and Regional Development Banks, in T.N Hale \& D. Held (Eds.), Handbook of Innovations in Transnational Governance, Polity Press, forthcoming.

D. Clark, The World Bank and Human Rights: The Need for Greater Accountability, 15 Harvard Human Rights Journal 206 (2002)

D. Clark, J. Fox \& K. Treakle (Eds.), Demanding Accountability: Civil-Society Claims and the World Bank Inspection Panel, Oxford: Rowman \& Littlefi eld Publishers Inc. (2003) 
K. Danaher (Ed.), 50 Years is Enough: The Case Against the World Bank and the International Monetary Fund, Boston, Massachusetts: South End Press (1999)

M. Darrow, Between Light and Shadow: The World Bank, the International Monetary Fund and International Human Rights Law, Portland, Oregon: Hart Publishing (2006)

J. Fox, The World Bank Inspection Panel: Lessons from the First Five Years, 6:3 Global Governance, 279 (2000)

K.W. Abbott, R.O. Keohane, A. Moravcsik, A. Slaughter \& D. Snidal, The Concept of Legalization, in J. Goldstein, M. Kahler, R. Keohane, A. Slaughter (eds), Legalization and World Politics, Cambridge, Mass., London: MIT Press (2001)

J.W. Head, For Richer or For Poorer: Assessing the Criticisms Directed at the Multilateral Development Banks, 52 University of Kansas Law Review 241 (2003)

K. Horta, Rhetoric and Reality: Human Rights and the World Bank, 15 Harvard Human Rights Journal, 227 (2002)

D. Hunter, Using the World Bank Inspection Panel to Defend the Interests of ProjectAffected People, 4 Chicago Journal of International Law, 201 (2003)

International Law Association, Accountability of International Organisations (2004)

B. Kingsbury, Operational Policies of International Institutions as Part of the LawMaking Process: The World Bank and Indigenous Peoples, in G.S Goodwin-Gill \& S. Talmon (Eds.), The Reality of International Law: Essays in Honour of Ian Brownlie, Oxford: Oxford University Press (1999)

B. Kingsbury, N. Krisch, R. B. Stewart, \& J.B. Wiener, Foreword: Global Governance as Administration - National and Transnational Approaches to Global Administrative Law, 68 Law \& Contemporary Problems 1 (2005) 
J. Klabbers, An Introduction to International Institutional Law, $2^{\text {nd }}$ Edition, Cambridge: Cambridge University Press (2002)

A. Naudé Fourie, The World Bank Inspection Panel and Quasi-Judicial Oversight: In Search of the 'Judicial Spirit' in Public International Law, Utrecht: Eleven International Publishing (2009)

C. Scott, Accountability in the Regulatory State, 27 Journal of Legal Studies 38 (2000)

I.F.I Shihata, The World Bank Inspection Panel: In Practice, Oxford: Oxford University Press (2000)

M. van Putten, Policing the Banks: Accountability Mechanisms for the Financial Sector, Montreal: McGill-Queen's University Press (2008)

K. Wellens, Remedies Against International Organisations, Cambridge: Cambridge University Press (2002) 


\section{Appendix}

\subsection{Structured comparison of OP\&P at MDBs}

\begin{tabular}{|c|c|c|c|}
\hline Institution & $\begin{array}{l}\text { Main policy areas covered by } \\
\text { OP\&P }\end{array}$ & $\begin{array}{l}\text { Adoption and amendment } \\
\text { procedures }\end{array}$ & Enforcement mechanisms \\
\hline World Bank $^{93}$ & $\begin{array}{l}\text { Poverty reduction } \\
\text { Country assistance management } \\
\text { Lending eligibility and terms } \\
\text { Safeguard policies: } \\
\text { Piloting the Use of Borrower Systems } \\
\text { to Address Environmental and Social } \\
\text { Safeguard Issues in Bank-Supported } \\
\text { Projects } \\
\text { Environmental Assessment } \\
\text { Environmental Action Plans } \\
\text { Natural Habitats } \\
\text { Water Resources Management } \\
\text { Pest Management } \\
\text { Indigenous Peoples } \\
\text { Social Assessment } \\
\text { Indigenous Peoples Plan } \\
\text { Physical Cultural Resources }\end{array}$ & $\begin{array}{l}\text { Most operational policies and } \\
\text { procedures are issued "under the } \\
\text { authority of the [Bank's] President", } \\
\text { by the relevant senior Bank } \\
\text { management member. Some policies, } \\
\text { such as the 'Safeguard policies', are } \\
\text { discussed by the Board in draft format } \\
\text { before they are adopted by Bank } \\
\text { management. (Shihata 2000, at 41-42) }\end{array}$ & $\begin{array}{l}\text { Inspection Panel (IP) } \\
\text { Independent Evaluation Group (IEG) } \\
\text { Quality Assurance Group (QAG) } \\
\text { World Bank's Department of } \\
\text { Institutional Integrity (INT) }\end{array}$ \\
\hline
\end{tabular}

\footnotetext{
${ }^{93}$ http://web.worldbank.org/WBSITE/EXTERNAL/PROJECTS/0,, contentMDK:21807601 menuPK:5068208 pagePK:41367 piPK:51533 theSitePK:40941,00.html.
} 


\begin{tabular}{|c|c|c|c|}
\hline Institution & $\begin{array}{l}\text { Main policy areas covered by } \\
\text { OP\&P }\end{array}$ & $\begin{array}{l}\text { Adoption and amendment } \\
\text { procedures }\end{array}$ & Enforcement mechanisms \\
\hline & $\begin{array}{l}\text { Involuntary Resettlement } \\
\text { Gender and Development } \\
\text { Forests } \\
\text { Safety of Dams } \\
\text { Bank financing } \\
\text { Legal aspects of lending } \\
\text { Emergency and other lending } \\
\text { instruments } \\
\text { Investment lending and the } \\
\text { Montreal Protocol } \\
\text { Procurement } \\
\text { Disbursement } \\
\text { Sanctions } \\
\text { Debt } \\
\text { Supervision } \\
\text { External resource mobilization and } \\
\text { aid coordination } \\
\text { Inspection Panel } \\
\text { communications with individual } \\
\text { executive directors } \\
\text { Information Disclosure }\end{array}$ & & \\
\hline
\end{tabular}




\begin{tabular}{|c|c|c|c|}
\hline Institution & $\begin{array}{l}\text { Main policy areas covered by } \\
\text { OP\&P }\end{array}$ & $\begin{array}{l}\text { Adoption and amendment } \\
\text { procedures }\end{array}$ & Enforcement mechanisms \\
\hline $\begin{array}{l}\text { International } \\
\text { Finance } \\
\text { Corporation }\end{array}$ & $\begin{array}{l}\text { Disclosure of information } \\
\text { Social and environmental } \\
\text { Sustainability policy } \\
\text { Performance standards: } \\
{ }^{96} \\
\text { Social and Environmental Assessment } \\
\text { and Management Systems } \\
\text { Labor and Working Conditions } \\
\text { Pollution Prevention and Abatement } \\
\text { Community Health, Safety and } \\
\text { Security } \\
\text { Land Acquisition and Involuntary } \\
\text { Resettlement } \\
\text { Biodiversity Conservation and } \\
\text { Sustainable Natural Resource } \\
\text { Management } \\
\text { Indigenous Peoples } \\
\text { Cultural Heritage } \\
\text { IFC's exclusions list } \\
{ }^{97}\end{array}$ & $\begin{array}{l}\text { Compiled by internal working } \\
\text { committees; } \\
\text { Submitted to Board of Executive } \\
\text { Director's Committee on } \\
\text { Development Effectiveness (CODE) } \\
\text { Adopted (and amendments approved) } \\
\text { by IFC's Board of Executive } \\
\text { Directors - no formal participation- } \\
\text { related or consultation requirements. }\end{array}$ & $\begin{array}{l}\text { Compliance Advisor/ Ombudsman } \\
\text { Independent Evaluation Group } \\
\text { World Bank's Department of } \\
\text { Institutional Integrity (INT) }\end{array}$ \\
\hline
\end{tabular}

\footnotetext{
${ }^{94}$ http://www.ifc.org/disclosure.
}

${ }^{95}$ Defining IFC responsibilities.

${ }^{96}$ Defining IFC borrower ('client') responsibilities. The disclosure of information policy, social and environmental sustainable policy and the performance standards together constitute the IFC's 'sustainability framework'.

${ }^{97}$ Listing project types the IFC are not allowed to finance. 


\begin{tabular}{|c|c|c|c|}
\hline Institution & $\begin{array}{l}\text { Main policy areas covered by } \\
\text { OP\&P }\end{array}$ & \begin{tabular}{|lll} 
Adoption and amendment \\
procedures
\end{tabular} & Enforcement mechanisms \\
\hline $\begin{array}{l}\text { Inter-American } \\
\text { Development Bank }^{98}\end{array}$ & \begin{tabular}{|l} 
General Operational Policies: \\
Disclosure of information \\
Operations programming \\
Lending policies \\
Technical cooperation \\
Procurement of goods and services \\
Subregional financial institutions \\
Sector Policies: \\
Multisectoral Policies: \\
Preinvestment \\
Intraregional Export Financing for \\
Goods and Services \\
Financing of exports through the \\
Venezuelan trust fund \\
Environment and Safeguards \\
Compliance \\
Natural Disaster Risk Management \\
Use of Intermediate or Light Capital \\
Technologies \\
Social Entrepreneurship Program \\
Maintenance and Conservation of \\
Physical Works and Equipment \\
Public Utilities \\
Subloan Interest Rates \\
Involuntary Resettlement
\end{tabular} & $\begin{array}{l}\text { Compiled by several internal working } \\
\text { committees; } \\
\text { Adopted (and amendments approved) } \\
\text { by IDB's Board of Executive } \\
\text { Directors - no formal participation- } \\
\text { related or consultation requirements. }\end{array}$ & $\begin{array}{l}\text { Office of Institutional Integrity } \\
\text { Independent Consultation and } \\
\text { Investigation Mechanism (MICI) } \\
\text { Office of Evaluation and Oversight }\end{array}$ \\
\hline
\end{tabular}

${ }^{98}$ http://www.iadb.org/en/about-us/operations-policies-of-the-inter-american-development-bank,6127.html. 


\begin{tabular}{|c|c|c|c|}
\hline Institution & $\begin{array}{l}\text { Main policy areas covered by } \\
\text { OP\&P }\end{array}$ & \begin{tabular}{|lll} 
Adoption and amendment \\
procedures
\end{tabular} & Enforcement mechanisms \\
\hline & $\begin{array}{l}\text { Information Age Technologies and } \\
\text { Development } \\
\text { Productive sectors } \\
\text { Economic infrastructure sectors } \\
\text { Social infrastructure sectors } \\
\text { Integrated development programs } \\
\text { Policies for special areas: } \\
\text { Women in Development } \\
\text { Indigenous Peoples }\end{array}$ & & \\
\hline $\begin{array}{l}\text { Asian } \\
\text { Bank }^{99}\end{array}$ & $\begin{array}{l}\text { Country classification and country } \\
\text { focus } \\
\text { Regional and subregional } \\
\text { cooperation } \\
\text { Sector and thematic policies: } \\
\quad \text { Poverty Reduction } \\
\text { Gender and Development } \\
\text { Incorporation of Social Dimensions } \\
\text { into ADB Operations } \\
\text { Governance } \\
\text { Anticorruption } \\
\text { Enhancing ADB's role in Combating } \\
\text { Money Laundering and the Financing } \\
\text { of Terrorism }\end{array}$ & $\begin{array}{l}\text { Adopted (and amendments approved) } \\
\text { by ADB's Board of Executive } \\
\text { Directors - no formal participation- } \\
\text { related or consultation requirements. }\end{array}$ & $\begin{array}{l}\text { Operations Evaluation Department } \\
\text { Accountability Mechanism }\end{array}$ \\
\hline
\end{tabular}

${ }^{99}$ http://www.adb.org/About/policies-strategies.asp. 


\begin{tabular}{|c|c|c|c|}
\hline Institution & $\begin{array}{l}\text { Main policy areas covered by } \\
\text { OP\&P }\end{array}$ & $\begin{array}{l}\text { Adoption and amendment } \\
\text { procedures }\end{array}$ & Enforcement mechanisms \\
\hline & $\begin{array}{l}\text { Business products and instruments } \\
\text { Partnerships } \\
\text { Safeguard policies } \\
\text { Analyses } \\
\text { Financial } \\
\text { Project administration: } \\
\quad \text { Project Performance Management } \\
\text { System } \\
\text { Consultants } \\
\text { Procurement } \\
\text { Loan Covenants } \\
\text { Effectiveness of the Loan Agreement } \\
\text { Disbursement } \\
\text { Project Accounting, Financial } \\
\text { Reporting, and Auditing } \\
\text { Independent evaluation } \\
\text { ADB Accountability Mechanism } \\
\text { Internal Audit } \\
\text { Public Communications }\end{array}$ & & \\
\hline
\end{tabular}




\begin{tabular}{|c|c|c|c|}
\hline Institution & $\begin{array}{l}\text { Main policy areas covered by } \\
\text { OP\&P }\end{array}$ & $\begin{array}{lll}\text { Adoption and } & \text { amendment } \\
\text { procedures } & & \end{array}$ & Enforcement mechanisms \\
\hline $\begin{array}{l}\text { European Bank for } \\
\text { Reconstruction and } \\
\text { Development }^{100}\end{array}$ & $\begin{array}{l}\text { Public Information Policy } \\
\text { Project Complaint Mechanism } \\
\text { (Independent Recourse } \\
\text { Mechanism) } \\
\text { Environmental and Social Policy } \\
\text { Environmental Procedures } \\
\text { Sub-sectoral environmental } \\
\text { guidelines } \\
\text { Procurement Policies and Rules } \\
\text { Internal Purchasing Policy and } \\
\text { Procedures } \\
\text { Anti-terrorist statement } \\
\text { Common performance assessment } \\
\text { report } \\
\text { Moving transition forward } \\
\text { Strategic Portfolio Review } \\
\text { Addressing staff grievances } \\
\text { Business plan and budget } \\
\text { Capital resources review }\end{array}$ & $\begin{array}{l}\text { Adopted by Board of Executive } \\
\text { Directors? }\end{array}$ & $\begin{array}{l}\text { Project Complaint Mechanism - } \\
\text { Office of the Chief Compliance } \\
\text { Officer }{ }^{101} \\
\text { (previously: Independent Recourse } \\
\text { Mechanism) }\end{array}$ \\
\hline
\end{tabular}

${ }^{100}$ http://www.ebrd.com/pages/about/policies.shtml.

${ }^{101}$ Also issue Anti-corruption reports 


\begin{tabular}{|c|c|c|c|}
\hline Institution & $\begin{array}{l}\text { Main policy areas covered by } \\
\text { OP\&P }\end{array}$ & \begin{tabular}{|lll} 
Adoption and amendment \\
procedures
\end{tabular} & Enforcement mechanisms \\
\hline & $\begin{array}{l}\text { EBRD and ethnic minorities } \\
\text { Political aspects of the EBRD } \\
\text { mandate } \\
\text { Fraud and corruption }\end{array}$ & & \\
\hline
\end{tabular}

${ }^{102}$ http://www.afdb.org/en/documents/policy-documents/. 


\begin{tabular}{|l|l|l|l|}
\hline Institution & $\begin{array}{l}\text { Main policy areas covered by } \\
\text { OP\&P }\end{array}$ & $\begin{array}{l}\text { Adoption and } \\
\text { procedures }\end{array}$ & Enforcement mechanisms \\
\hline & $\begin{array}{l}\text { Handbook on Stakeholder } \\
\text { Consultation and Participation in } \\
\text { AfDB Operations } \\
\text { Policy on Cross-Cutting Issues } \\
\text { Sectoral Policy } \\
\text { Special Initiatives } \\
\text { Procurement } \\
\text { Integrity and Anti-Corruption } \\
\text { Information Disclosure }\end{array}$ & \\
& & \\
\hline
\end{tabular}

